\title{
Protection of groundwater dependent ecosystems in Canterbury, New Zealand: the Targeted Stream Augmentation Project
}

\author{
Brett Painter ${ }^{1}$
}

Received: 3 November 2016/Accepted: 27 August 2017/Published online: 12 September 2017

(c) The Author(s) 2017. This article is an open access publication

\begin{abstract}
In Canterbury, New Zealand, native aquatic species habitat has significantly declined over the last century due primarily to land use change and climatic influences. The Canterbury Water Management Strategy (CWMS) aims to improve such habitat while also meeting other economic, environmental, social and cultural objectives. The focus of this paper will be on the Targeted Stream Augmentation (TSA) Project in the Selwyn-Waihora Zone in Canterbury. The semi-arid climate, significant demand for irrigation water and the up-gradient aquifer pressure provided by a coastal lake provide significant aquifer management challenges in this zone. In response to these challenges the local CWMS committee recommended that managed aquifer recharge trials to improve groundwater dependent ecosystems start in a highly targeted manner before gradually increasing the distance from recharge site to the target spring/s. A highly targeted pilot trial has shown the flow, temperature and nutrient concentration benefits for the target surface ecosystem. The implementation of two larger scale concepts combining surface and groundwater ecosystem benefits is now progressing. Lessons learned to date include the importance of keeping engagement processes ahead of technical assessments, and the benefits of high level scoping assessments before committing to detailed investigations and pilot projects.
\end{abstract}

Keywords Native species habitat - Targeted recharge and discharge $\cdot$ New Zealand

This article is part of the special issue on Managed Aquifer Recharge.

Brett Painter

brett.painter@ecan.govt.nz

1 Canterbury Regional Council, Christchurch, New Zealand

\author{
Abbreviations \\ CPW Central Plains Water scheme \\ CWMS Canterbury Water Management Strategy \\ MAR Managed aquifer recharge \\ TSA Targeted Stream Augmentation
}

\section{Introduction}

\begin{abstract}
Aim
The aim of this paper is to introduce the Selwyn-Waihora Zone (in New Zealand), investigations to assess the potential role of managed aquifer recharge (MAR) concepts in the zone, and the current status of 'next steps' MAR implementation. This zone has complexities in geology, water cycle processes and decision-making processes. The Canterbury Water Management Strategy (CWMS) has provided an opportunity for a wide variety of water stakeholders to develop a collective understanding of system complexities and agree on water management changes. The construction of the Central Plains Water irrigation scheme has provided opportunities to add infrastructure for MAR at much lower cost than for a standalone scheme. Cost and technology improvements in solar powered pumping have also enabled a highly targeted recharge concept to be progressed.
\end{abstract}

\section{Study area}

Canterbury is New Zealand's largest region comprising approximately $17 \%$ of the country's land area. The region currently accounts for approximately $60 \%$ of all water allocated for consumptive use in New Zealand and $70 \%$ of the nation's irrigated land. The Selwyn-Waihora Zone in 
Canterbury is named after the intermittent Selwyn River (with hill-fed flow in the upper catchment and groundwater-fed lowland flow), and Te Waihora/Lake Ellesmere which is a large coastal lake that is no longer the 'food basket' that previous generations enjoyed (see Fig. 1). The aquifer underlying this zone primarily comprises glacial and postglacial outwash gravels of up to $600 \mathrm{~m}$ thickness, except in the lower catchment where layers of sediment create more defined aquifer layers, with the shallow aquifer feeding lowland streams (and the lake directly through its bed). Most lowland streams between the Selwyn and Rakaia Rivers (e.g., Boggy Creek) are fed by springs within $10 \mathrm{~km}$ of the lake. The Selwyn River also flows in its mid-reaches when groundwater levels are sufficient (or in large floods) and feeds the upper reaches of the Irwell River during these circumstances through preferential underground channels (from an old river course).

Te Waihora (meaning "spreading waters") has spent less than 5000 years in its current state as a brackish barlagoon. In this time period lake depth could reach $4 \mathrm{~m}$ before over-topping the sea barrier. Early Māori settlers manually opened the lake at approximately $2 \mathrm{~m}$ depth to maximise its potential as a natural 'food basket'. Since 1947 the lake depth has been managed by mechanical opening to the sea when sea conditions permit and lake depth reaches $1.05 \mathrm{~m}$ (summer) or $1.13 \mathrm{~m}$ (winter). The combination of this lower lake opening regime and a drainage scheme in the lower plains (see Fig. 2) has kept the lake area to approximately $200 \mathrm{~km}^{2}$ and enabled increased agricultural use near the lake edge. Flooding risk to the lakeside community is heightened during sustained rainfall combined with rough sea conditions that delay lake opening. As well as surface flooding, a high lake also backs up the shallow aquifer system, causing flooding further upcatchment. The lakebed was legally vested in Te Rūnanga o Ngāi Tahu (local Māori tribe) under the Ngāi Tahu Claims Settlement Act 1998. Te Waihora/Lake Ellesmere was then subject to a Joint Management Plan (2005) between the Department of Conservation and Te Rūnanga o Ngāi Tahu and the National Water Conservation (Te Waihora/Lake Ellesmere) Order 1990 was amended in 2011 to recognize the indigenous vegetation and cultural values of the lake. In 2012 a co-governance agreement for the zone was signed between Canterbury Regional Council, Te Rūnanga o Ngāi Tahu and Te Waihora Management Board. Selwyn District Council and Christchurch City Council also have resource management responsibilities. Progressing water management concepts in the SelwynWaihora Zone, therefore, requires significant consultation and collaboration.

The lower catchment has a coastal island climate, with approximately $650 \mathrm{~mm} /$ year rainfall (but ranging from 300 to $1000 \mathrm{~mm} /$ year) and $800-900 \mathrm{~mm} /$ year evapotranspiration. Rainfall increases to approximately $1000 \mathrm{~mm} /$ year in the foothills and $4000 \mathrm{~mm} /$ year at the headwaters of the alpine rivers (e.g., Rakaia River) in the Southern Alps. Evapotranspiration also decreases as rainfall increases up the catchment. Periods of low rainfall in the coastal zone are often accompanied by high rainfall in the alps from westerly weather systems. Future climate analyses
Fig. 1 Selwyn-Waihora Zone, New Zealand with key waterways and TSA sites (1-3)

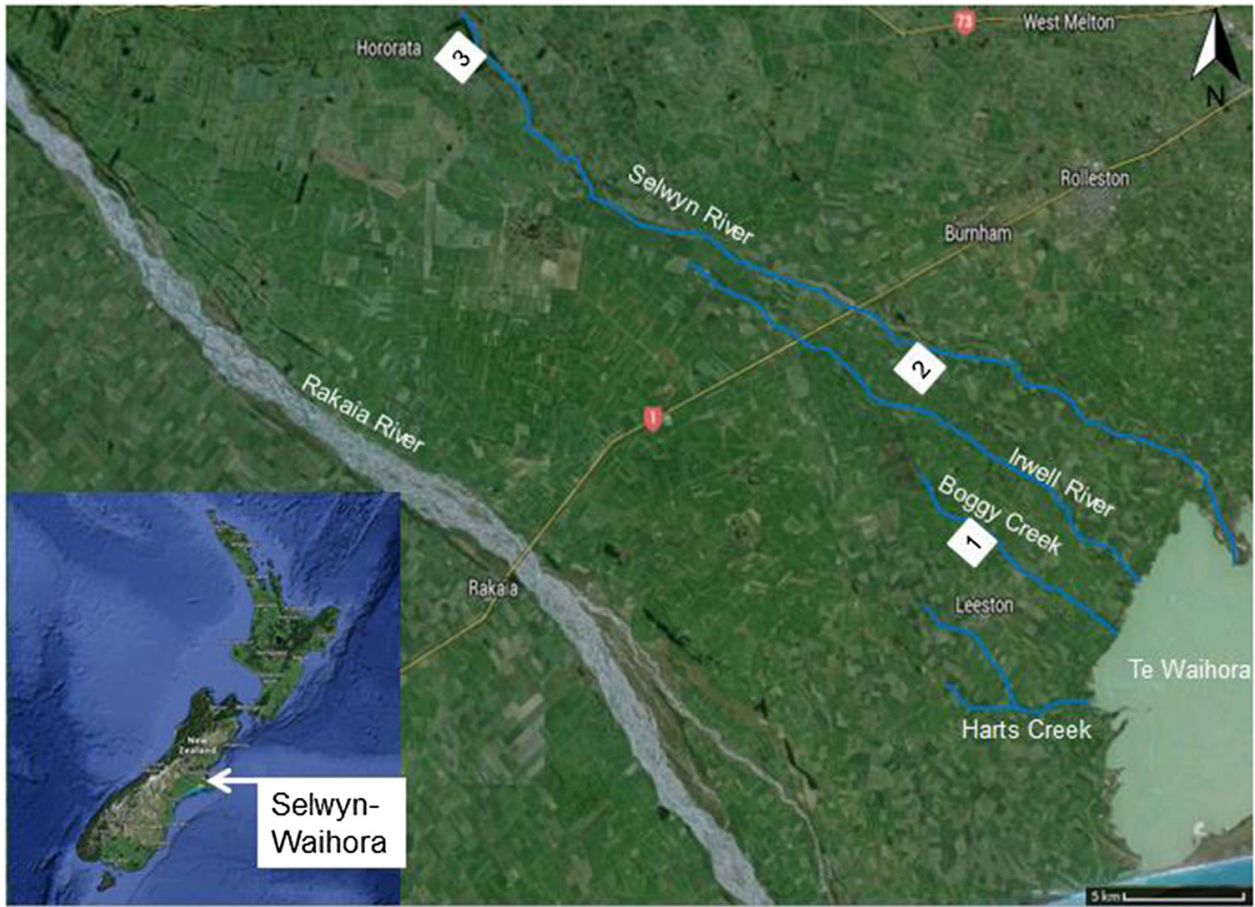


Fig. 2 Selwyn-Waihora Zone, water infrastructure and Canterbury Mudfish habitat

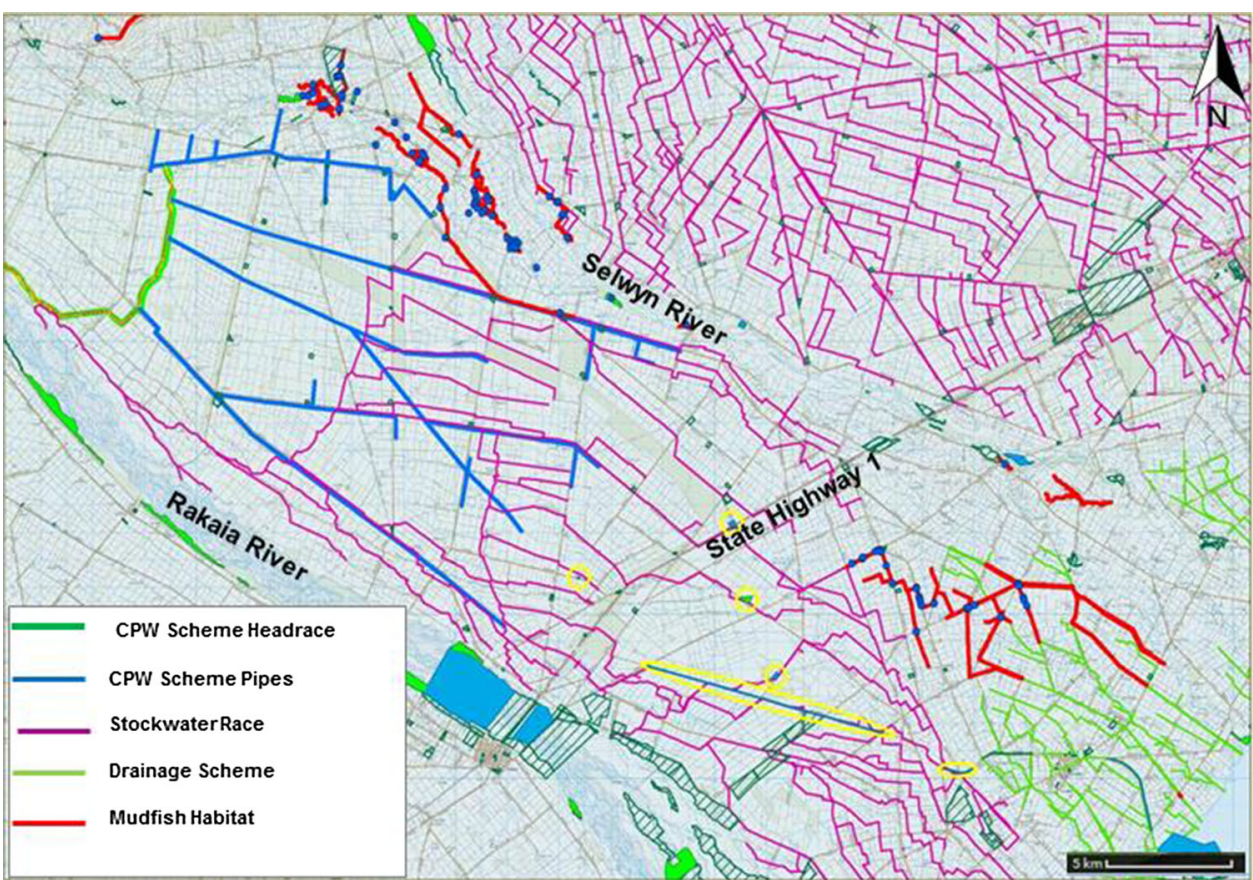

(Zammit and Woods 2011; Bright 2011) suggest that the plains (and underlying aquifer) and lowland catchment are likely to continue getting drier, while the alpine area is likely to get wetter (especially late winter and early spring with less rain staying as snow in the alps). Natural recharge from the alpine rivers into the connected plains aquifer system doesn't seem to change much with river flow; however, the alpine rivers also provide MAR opportunities where there is existing distribution infrastructure. For the last 120 years, the $500 \mathrm{~km}$ of unlined water races between the Selwyn and Rakaia Rivers (see pink lines in Fig. 2) have recharged approximately $90 \%$ of their flow as they deliver water, primarily for stock drinking. These races have also provided a range of ecological values due to their flow permanence, including habitat (see red lines in Fig. 2) for the Canterbury Mudfish (Neochanna burrowsius) which is currently classified as "At Risk: Nationally Critical" (Goodman et al. 2014) due to predation, agricultural encroachment into traditional lowland swamp habitat, climatic and irrigation abstraction effects on lowland stream flows. The Canterbury Mudfish (Waikaka in Māori) is also listed as a taonga (treasured) species in the Ngāi Tahu Claims Settlement Act 1998.

The water race system (mostly on private land) is gradually being shut down and filled in as the races are getting in the way of modern irrigation infrastructure and stock water can be delivered along with irrigation water through the lined canals and pipes of the new Central Plains Water (CPW) scheme. ${ }^{1}$ The CPW scheme delivers

\footnotetext{
${ }^{1}$ http://www.cpwl.co.nz
}

water from the Rakaia River (intake at top left of Fig. 2) and nearby storage lake, through a lined canal across the top of the plains (green line in Fig. 2) and then to shareholders via underground pipes (blue lines in Fig. 2). The current scheme became operational in the spring of 2015 . A 20,000 ha extension to the scheme is expected to be operational by spring 2018. Approximately 16,000 ha of the 23,000 ha worth of irrigation water delivered to CPW stage 1 between the Selwyn River, Rakaia River and State Highway 1 is replacing current consents to take deep groundwater. The shutdown of the water race system means a reduction in aquifer recharge from race leakage and a reduction in ecosystem habitat for species such as the Canterbury Mudfish. However, the replacement of groundwater takes with surface water from the CPW Scheme means that the aquifer benefits from less abstraction and additional land surface recharge from any over irrigation. The new CPW infrastructure also provides opportunities to deliver currently consented stockwater (freed up by water race shutdown) to sites that support ecosystem benefits. High reliability takes from the Rakaia River are limited to rural drinking and stockwater, and environmental enhancement by the National Water Conservation (Rakaia River) Order 1988.

\section{Social context}

Agricultural land uses have dominated the Selwyn-Waihora Zone since European settlement in the mid-1800s. The construction of the stock water schemes in the late $1800 \mathrm{~s}$ plus a small number of groundwater bores provided 
sufficient water most years until a multi-year dry spell in the late 1960s and further dry spells in the 1980s and 1990s. Landowner response to the dry conditions was a dramatic increase in applications to take and use groundwater in the 1990s. This created a classic "tragedy of the commons" (Hardin 1968) situation where the cumulative effects of a drying climate and increased abstraction were particularly tragic for the freshwater species that relied on sufficient length of flowing waterways (Painter and Memon 2007; Painter 2009). As adversarial water allocation processes became the norm (Weber et al. 2011), central and local government led early research into water storage and distribution opportunities ${ }^{2}$ and local researchers led a project with local water stakeholders to identify more equitable and sustainable water management options (Painter and Bright 2006; Memon et al. 2010). These projects were followed by confirmation of the $\mathrm{CWMS}^{3}$ in 2009.

The CWMS set up ten zone committees and a regional committee, empowering them to work collaboratively to develop effective water management solutions that deliver economic, social, cultural and environmental outcomes defined by their local community. Initial investigations to assist CWMS committee deliberations included a preliminary assessment of MAR concepts against the CWMS Principles and Targets (PDP 2010) and initial MAR feasibility studies (SKM 2010, Golder Associates 2013).

With the delicate balance between too little water and too much water in the lower catchment and the large distance between potential recharge areas and the lowland streams, the Selwyn-Waihora CWMS Zone Committee recommended that a series of pilot studies be undertaken, starting with recharge very close to the target stream, then an aquifer recharge experiment slightly further up-gradient from the target stream/s. The Zone Committee named the project the Targeted Stream Augmentation (TSA) Project, a title and concept similar to "targeted near-stream recharge" (e.g., Lacher et al. 2014).

\section{Materials and methods}

Managed aquifer recharge has been described as the purposeful recharge of water to aquifers for subsequent recovery or environmental benefit (e.g., Dillon et al. 2009). Assessing the feasibility of MAR requires the integration of many types of data and information from many disciplines. Overviews of the basic requirements and feasibility

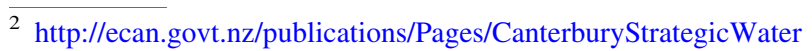
Study.aspx.

${ }^{3}$ http://ecan.govt.nz/get-involved/canterburywater/pages/default. aspx.
}

guidelines for MAR have previously been described (e.g., Dillon et al. 2009; Gutteridge et al. 2011; Rawluk et al. 2012; Arshad et al. 2014). These requirements include:

- Stakeholder engagement and social acceptance assessments;

- Hydrology and hydrogeology assessments;

- Environmental risk assessments;

- Engineering method assessments;

- Regulatory and institutional assessments;

- Financial and economic assessments.

The order of assessments and engagement processes as well as the staging of assessment details were found to be important factors in progressing the MAR concept for the Selwyn-Waihora Zone. The scope of the project was defined by Recommendation 1.8(a) of the Selwyn-Waihora Zone Implementation Programme Addendum ${ }^{4}$ :

"The Sub-regional Chapter will support use of MAR or other methods of augmentation to increase base flows in lowland streams subject to a source of water being available, feasibility, and acceptability from a cultural viewpoint about mixing of waters, and other issues such as groundwater mounding in the lower catchment."

With no specific future funding source tied to implementation of MAR concepts, key considerations in progressing the project were developing stakeholder relationships, maximizing use of existing infrastructure, and identifying current and potential future funding avenues. Addressing the water source availability recommendation required:

- Reference to a recent ecological assessment of the water race system (EOS Ecology 2011) and updated assessments to identify Canterbury Mudfish habitat target areas.

- Legal analysis of the National Water Conservation (Rakaia River) Order 1988 to determine whether MAR was a legitimate alternative use of currently consented stockwater (not subject to minimum flow rules);

- On-going discussion with Central Plains Water scheme developers and analysis of potentially spare capacity in their infrastructure at different times of the year;

- On-going discussion with Selwyn District Council and their committee responsible for management of the water race network;

- On-going discussion with landowners who have waterway ecosystems on their property that could benefit from more reliable flow;

\footnotetext{
$\overline{4}$ http://ecan.govt.nz/publications/General/zip-addendum-at-150613v6.pdf.
} 
- On-going discussion with landowners who have current water races on their property that could be required for delivery of recharge water; and

- Analysis of resource management rules regarding consents for take and use of groundwater in the Selwyn-Waihora Zone.

Addressing the feasibility and groundwater mounding considerations required:

- Coupled ground and surface water modelling to understand the potential long term effects of different MAR concepts;

- Engineering and land ownership assessments of current water races that could be required for delivery of recharge water;

- Water quality analysis of source and receiving waters; before, during and after all experiments;

- Analysis of existing geology and hydrogeology information, including LIDAR surveys and cores taken from relevant groundwater bores; and

- Design, assessment of environmental effects, consenting, construction, implementation, and analysis of pilot experiments.

Addressing the cultural and social acceptance considerations required:

- On-going discussions with Te Taumutu Rūnanga (the local sub-tribe of Ngāi Tahu) regarding source and receiving waters, their characteristics, methods of mixing and any required mitigations;

- On-going discussions with other project partners (e.g., Selwyn-Waihora Zone Committee, Selwyn District Council, Department of Conservation, affected landowners) to ensure their input into and acceptance of each step of the project; and

- On-going communication with a range of potentially interested parties.

\section{Results}

\section{Initial assessments}

\section{Ecosystem values}

The aim of the TSA Project is to provide targeted flow support for a range of ecosystem values. Determining currently present species along with their current and future potential habitat were key initial assessments. An assessment of ecological values of the current water race system was carried out in 2011 (EOS Ecology 2011). Of the 31 sites surveyed, 12 were classified as HIGH ecological value, 7 were classified as MODERATE ecological value and 12 were classified as LOWER ecological value. Key species included Canterbury Mudfish (a native galaxiid with "At Risk: Nationally Critical" status), freshwater mussels, freshwater crayfish and aquatic snails. The only nationally significant race system for ecosystem values (primarily Mudfish value) was an area immediately upgradient from Boggy Creek.

Follow-up studies (e.g., O'Brien 2015) have tracked the status of known Mudfish populations and temporary habitat has been found for populations most at risk of extinction due to the lack of water supplying their habitat over the last few summers. Sites prioritized for future flow support either contain Mudfish populations with risk of future reduced inflows (e.g., due to future water race closures) or sites with potentially suitable habitat if sufficient flow could be provided. Canterbury Mudfish prefer slow-flowing, meandering swampy streams disconnected from the habitat of their main predators (e.g., trout and eels). When surface flow disappears they burrow into the bed of the waterway where they have been found to survive for up to 3 months without flowing water (e.g., O'Brien 2015).

Figure 2 shows historical Canterbury Mudfish habitat to 2014. By late summer 2015 the upper Selwyn River population had all but disappeared due to trout predation in connected reaches and a combination of drought and habitat destruction in the disconnected reaches. The lower catchment population had survived on flow through the stockwater race system, but this flow is not guaranteed into the future as the races are gradually shut down. New populations were found nearby in the 2014/15 survey fed by springs of the Irwell and a lower Selwyn River tributary, and a 2014 Irwell River flow survey under high groundwater conditions identified additional potential habitat in disconnected reaches further up the Irwell system. This prioritized tributaries near the Irwell and Selwyn Rivers and water races up-gradient from Boggy Creek for TSA Project pilot studies.

\section{Water supply}

Potential water supply analysis considered groundwater and surface water options. Although the Canterbury Land and Water Regional Plan ${ }^{5}$ provides significant constraints to allocating consumptive groundwater in the SelwynWaihora Zone, the conjunctive management of ground and surface water systems along with specific rules to support MAR/TSA provides strong support for MAR/TSA Projects.

\footnotetext{
5 http://www.ecan.govt.nz/our-responsibilities/regional-plans/lwrp/ Pages/plan-decisions-version.aspx.
} 
The most promising surface water supply identified was currently consented stockwater from the Rakaia River. This flow is exempt from minimum flow restrictions and the demand for the allocated flow is reducing as the leaky stockwater race system is gradually being shut down. A legal opinion concluded that an additional use (MAR/TSA) for the currently consented stock water was not contrary to the minimum flow exemption rules in the National Water Conservation (Rakaia River) Order 1988. This meant that stockwater could be delivered for MAR/TSA, initially via current stockwater races, and could in future (with consent amendments) also be delivered by CPW infrastructure. $732 \mathrm{l} / \mathrm{s}$ is currently consented to be taken from the upper Rakaia stockwater intake and $500 \mathrm{l} / \mathrm{s}$ from the lower Rakaia intake. CPW consented water for irrigation has also been confirmed as another potential supply source. This water is consented all year round so that winter flows can be stored in a lake near the Rakaia River Gorge. CPW have offered excess consented water for TSA Projects connected to their infrastructure. Pre-construction analysis of the CPW stage 1 potential demand and distribution sizing suggested that average pipe capacity utilization in the height of the irrigation season would reach approximately $85 \%$. This figure will be updated over the coming years to understand where supply capacity could match TSA demand. Confirmation of CPW stage 2 design in recent months has also provided near river recharge opportunities, particularly where the new main pipeline is expected to travel under the Selwyn River (Site 3 on Fig. 1). The operational cost of delivering this MAR/TSA water is not significant provided only the gravity-fed sections of the scheme are used.

\section{Initial computer modelling}

The water quantity computer model utilized by the SelwynWaihora Zone Committee to develop their future planning recommendations was also used for the initial TSA concept scenarios. Separate water quality modelling of the conceptual TSA scenarios was undertaken to estimate the potential nitrate reduction in groundwater from managed recharge of low nitrate source water. Distributed recharge (using stockwater races) across the upper plains and basin (or dry tributary) recharge near Boggy and Harts Creek were modelled. The water quantity modelling showed that the majority of shallow aquifer flow (natural plus TSA) moves through the areas of high permeability alluvial gravels and around the swampy areas near the lower Irwell and Boggy Creek. This is good news for Harts Creek recharge but not so good for Boggy Creek or Irwell River unless the recharge site is close to a target spring. As improved aquifer levels from the CPW scheme were also expected to mainly benefit Harts Creek, the area from the
Selwyn River to Boggy Creek was prioritized for progressing TSA. The water quantity modelling also showed that the greatest benefits to the target groundwater-fed waterways occurred during low to medium flows. Potential contribution to flooding in lower catchment waterways was shown to be very small. This was an important positive message for lower catchment landowners. The water quality modelling showed Nitrate-Nitrogen concentration reduction of up to $10 \%$ for target waterways from the modelled scenarios. The message that TSA would improve water quality but not replace land use and on-farm nutrient management as the key water quality management tool was also received positively by the communities of interest.

\section{Existing distribution infrastructure}

The next set of assessments considered capacity, infrastructure and land ownership for water races between potential recharge sites and CPW scheme main distribution pipes. Assessments included required infrastructure to connect to the CPW pipe, potential distribution losses, channel capacity and culvert capacity. A survey assessment to identify the sections of water race on private land versus public land was also undertaken.

The channel and culvert assessment of the current stockwater race feeding native fish habitat between Boggy Creek and the lower Irwell River concluded that current supply was limited to approximately $50 \mathrm{l} / \mathrm{s}$ immediately up-gradient from the target race/recharge area with $120-150 \mathrm{l} / \mathrm{s}$ restrictions further up-gradient to the main railway line. The modelled concept was for 500 1/s. Annual cleaning costs for the supply race were estimated at NZD 20,000 per year by the district council. Race losses (aquifer recharge and evaporation) were assessed at $5-10 \mathrm{l} / \mathrm{s} / \mathrm{km}$ upgradient from Main South Road, with lower losses expected in the down-gradient section. This would mean that at least $100 \mathrm{l} / \mathrm{s}$ additional flow would need to be supplied to the race in addition to the TSA flow, though most of this flow would still provide distributed benefit to the lowland streams via aquifer recharge.

Based on the above analyses, it was recommended that the district council keep the current supply race open for direct support to the native fish habitat until alternatives had been fully assessed. A TSA experiment in the vicinity of the Boggy Creek system was also recommended, with already consented groundwater (available out of the irrigation season) as the supply source.

\section{Boggy Creek TSA experiment using groundwater}

Lowland stream ecosystem habitat is placed under significant pressure during dry periods with stable low (or no) flows, elevated nutrients and elevated temperatures. The 
purpose of the Boggy Creek TSA experiment (Site 1 on Fig. 1) using deep groundwater was to understand the benefits and challenges of highly targeted flow support for these systems. The reason for using groundwater from the third aquifer ( $\sim 60 \mathrm{~m}$ below ground level) was to minimise the stream depletion effects that would occur with utilizing shallower groundwater. Future aquifer storage benefits from the CPW scheme are also expected to be most noticeable in the deeper (third and fourth) aquifers. The cost of drilling a deep well for the pilot experiment was not financially viable, so a member of the Zone Committee (and chair of the local drainage committee) offered their existing irrigation well provided the experiment was run outside the irrigation season.

With reduced lowland stream flows following a dry 2014/15 summer, the key factors that could be investigated from an experiment during the winter of 2015 were flow, nutrient concentration and dissolved oxygen. The chosen reach is groundwater-fed during normal groundwater levels, but can also lose to groundwater when groundwater levels are low. Losses to groundwater will generally feed the same tributary further down-gradient or the lake itself through springs in the lake bed. Groundwater in this part of the catchment is highly connected to lake level in Te Waihora, so can be changed by opening the lake to the sea as well as local runoff and upper catchment influences. Groundwater recharge effects were therefore not considered directly for this experiment.

Figure 3 presents the monitoring sites and median water quality measurements for the Boggy Creek experiment.
Boggy Creek used to meander in multiple spring-fed channels at this point but is now channelized to follow the roads from the top of the figure to the lower right hand corner. The two meandering reaches in the figure usually only flow now when the shallow groundwater table is high or following rain events. These reaches were dry prior to the TSA experiment. Flow direction for all Fig. 3 reaches is shown by the black arrows. Sampling site BSC1 is upstream from all flow augmentation and site BCS5 downstream. Site BCS2 is immediately upstream from discharge point 1 (DP1) and site BCS3 immediately downstream from DP1 (but upstream from the main channel). Site BCS4 is upstream from discharge point 2 (DP2). The supply water for both discharge points is provided by well M36/4513. Comparison of the well and surface water median measurements shows the groundwater to be slightly higher in temperature, but significantly lower in dissolved oxygen (DO) and Nitrate-N.

A comparison of all dissolved oxygen (DO) measurements in Fig. 3 shows that the supply mechanism (perforated pipe over cobbles) successfully mitigated the low groundwater oxygen levels. A comparison of all temperature measurements shows a $3.2^{\circ} \mathrm{C}$ increase, which was found to be within the normal range of variation for the time of year. It was, however, noted that the temperature difference is expected to be greater in the summer (with groundwater cooler than surface water during this period). A comparison of all Nitrate- $\mathrm{N}$ concentrations shows a significant concentration decrease due to the TSA experiment, with the downstream concentration of $2.2 \mathrm{~g} / \mathrm{m}^{3}$ not
Fig. 3 Median water quality measurements during the Boggy Creek TSA experiment

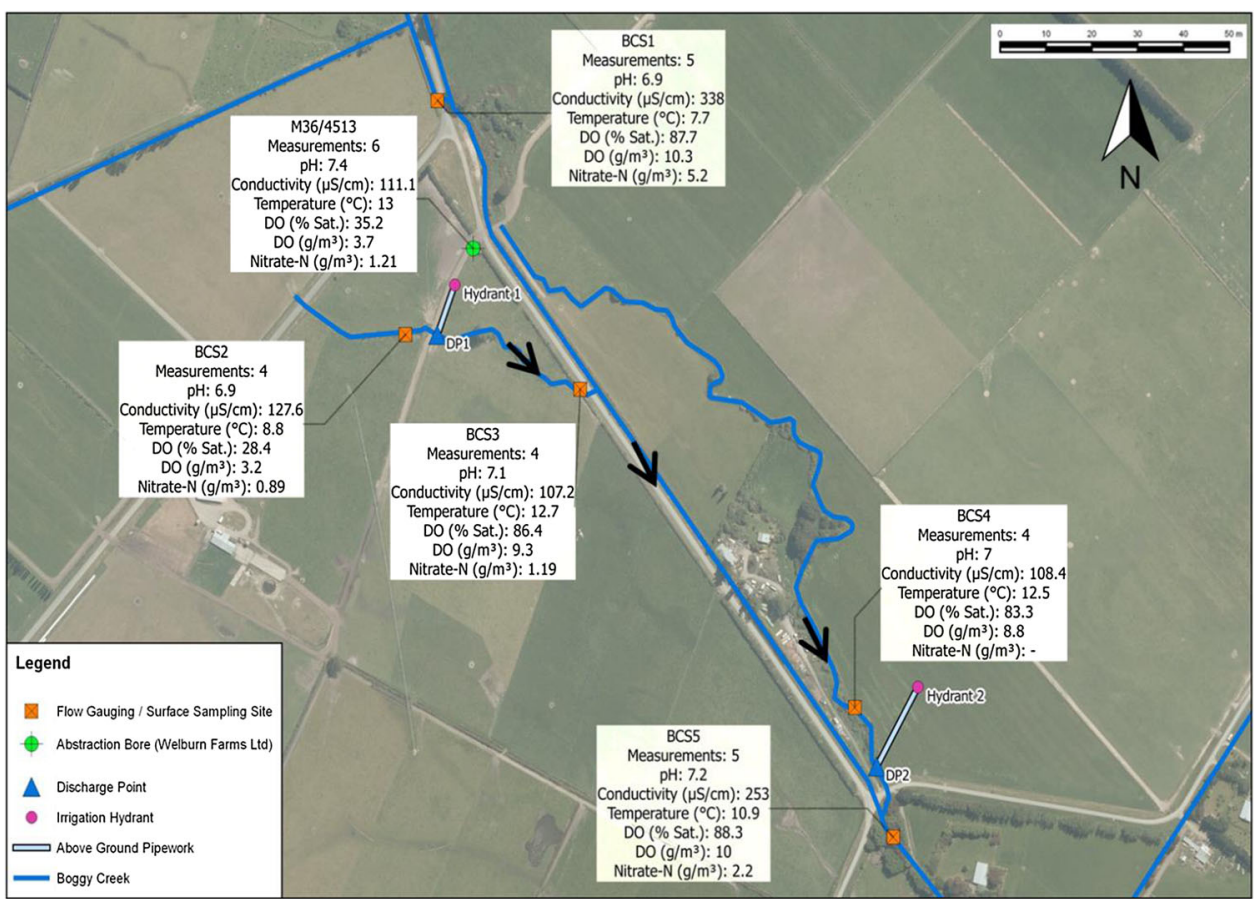


far above the $95 \%$ species protection level of $1.7 \mathrm{~g} / \mathrm{m}^{3}$ $\mathrm{NO}_{3}-\mathrm{N}$.

Figure 4 shows the Boggy Creek flow, local rainfall and TSA flow before, during and after the experiment. Pre-experiment flow $(\sim 221 / \mathrm{s})$ was well below average for the winter, so the $60 \mathrm{l} / \mathrm{s}$ supplied (half at each discharge point) made a significant difference once bank storage in the dry tributary channels had filled up. Rainfall greater than $6 \mathrm{~mm}$ in a day was also shown to produce a noticeable Boggy Creek flow response. Aquifer recharge down-gradient from the monitored section could have been occurring, but this information was not relevant to the experiment.

\section{Next steps}

With the Boggy Creek experiment confirming ecosystem benefits from near-stream discharge, project stakeholders agreed to the construction of a solar powered groundwater bore to augment at a different location. The new site was beside the natural spring for a tributary of the Selwyn River with previously significant native fish habitat (including a designated Canterbury Mudfish habitat reach) that had been dry for an extended period with total species loss. The tributary location is identified as Site 2 in Fig. 1 and in
Fig. 2 by the red lines in the shape of a horizontal Y, above the main mudfish habitat in the lower portion of the figure.

A supply bore plus three groundwater monitoring bores have been installed to date. Bore testing showed aquifer recharge back through the up-gradient spring (due to current low groundwater levels) as well as down-gradient tributary flow and aquifer recharge through the bed of the tributary. Habitat enhancements by lining pools in the tributary have therefore been designed in case aquifer recharge needs to be reduced through the designated mudfish habitat. Additional down-gradient monitoring will assist with understanding the extent of additional shallow groundwater and spring-fed surface water support. The solar panels and pump are being installed during the first quarter of 2017 followed by habitat enhancements. Canterbury Mudfish are being bred in a nearby sanctuary for translocation when the habitat is deemed ready. Two local schools will be involved, through classroom studies on Canterbury Mudfish followed by participation in the translocation.

Near river recharge of the upper Selwyn River is also progressing (Site 3 in Fig. 1), now that final CPW stage 2 design is confirmed. New monitoring is in place around the upper Irwell spring to aid understanding of the local ground and surface (Selwyn River) connections to the spring. The

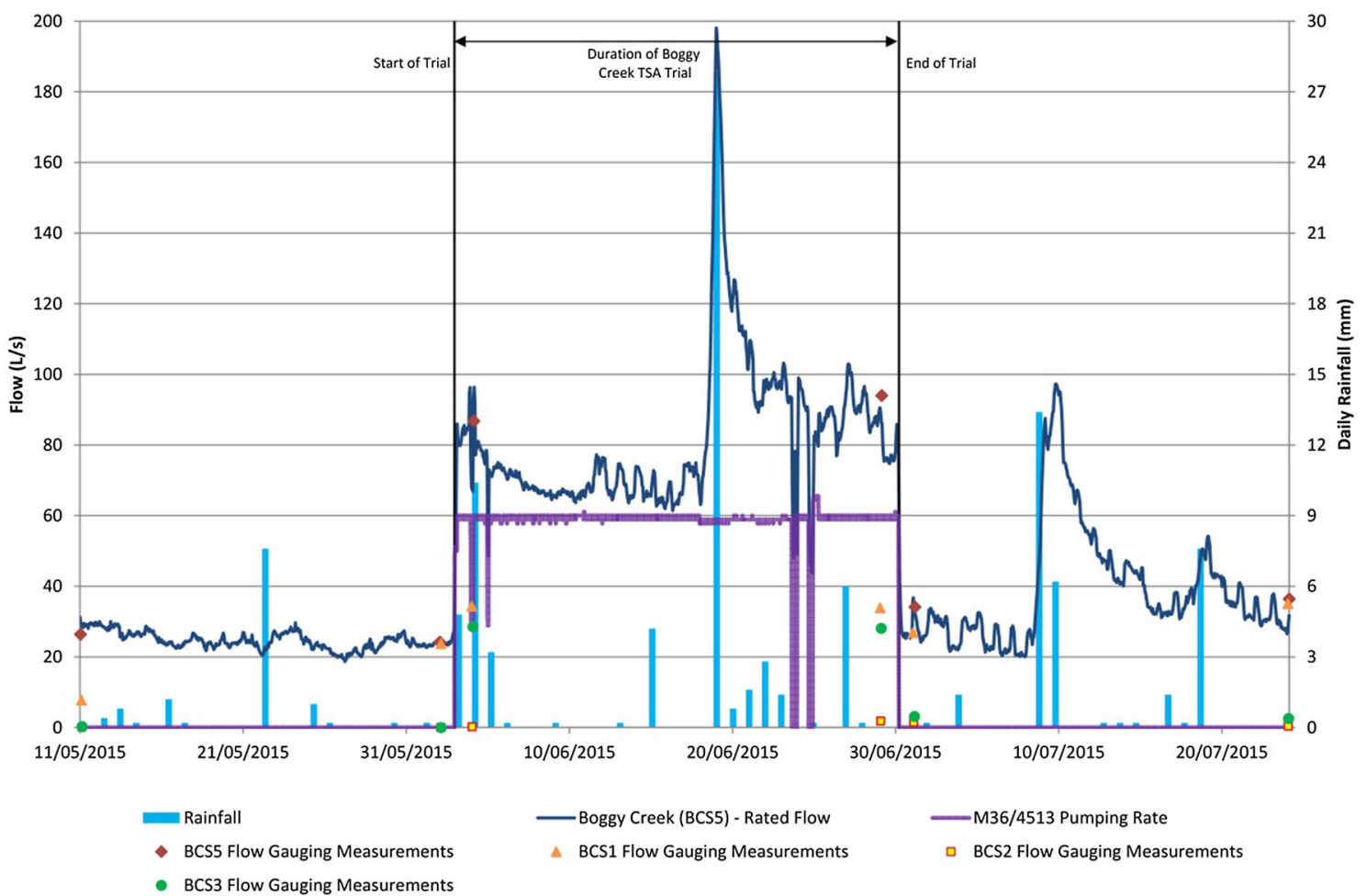

Fig. 4 Stream flow, local rainfall and TSA flow for the Boggy Creek TSA experiment 
recharge concept involves connection to a high pressure irrigation pipe, pressure reduction infrastructure, an initial recharge area beside the flood plain of the Selwyn River, then direction of the recharge flow into the flood plain of the river.

Previous research (Larned et al. 2007) concluded that the Selwyn River loses approximately 500 1/s to groundwater in the target reach for every kilometer of river bed. This means that a significant flow can be discharged to the bed of the river without any direct mixing with the main Selwyn River channel. Commissioning would start small with key cultural and environmental outcomes monitored. The Larned et al. study showed that a significant portion (approximately 50\%) of the river losses in this reach feeds the Haldon Springs (upper plains mudfish habitat in Fig. 2), which flow into the Hororata River and then back into the Selwyn River system. The native and recreational fish values of the Haldon/Hororata reaches will, therefore, benefit as will the values of the connected groundwater system which supports the Irwell River and lower Selwyn River systems.

\section{Discussion and conclusion}

Investigations and on-going consultation with project stakeholder representatives have identified challenges and opportunities for TSA/MAR throughout the southern section of the Selwyn-Waihora Zone. The key opportunities are the wide community involvement in the CWMS and the construction of the CPW irrigation scheme. The key challenges are balancing investigations and community buy-in with construction schedules as well as confirming sufficient funding for public good projects in tight timeframes. A staged and collaborative approach to developing and testing concepts has been utilized in response to concerns raised about progressing catchment scale MAR concepts while the connected ground and surface water system is currently changing due to the new CPW scheme, gradual shutdown of the stockwater race network and climatic effects. This approach has encouraged on-going colearning and collaboration between project stakeholder representatives. Recent dry summers and loss of habitat for the endangered Canterbury Mudfish have provided short term goals, while the longer term outcomes identified by the Selwyn-Waihora Zone Committee will assist with project longevity.

Flow support solutions are now in place or underway for the three key Canterbury Mudfish areas shown in Fig. 2. Stockwater race distribution is confirmed in the medium term for supplying habitat in the large area of historical swamp up-gradient from Boggy Creek, with solar powered pumping a future back up. A solar powered pump and habitat improvements are under construction for the lower Selwyn River tributary and a near river recharge concept is in the detailed design phase for the upper Selwyn River. These solutions are based on development of a collective understanding of the connected climate, human, surface and groundwater systems, then testing tailor-made management concepts for each situation. The importance of the CWMS in this achievement cannot be understated. It provides a politically approved process for community collaboration and an imperative to jointly progress economic, environmental, social and cultural objectives in every situation.

Acknowledgements Significant assistance with field work and reporting has been provided by Pattle Delamore Partners and with computer modelling by Aqualinc Research.

\section{Compliance with ethical standards}

Funding Primary funding for this project has been provided by the Canterbury Water Management Strategy (funded through a regionwide rate). Secondary funding has been provided by a targeted rate to the Selwyn-Waihora Zone.

Conflict of interest The author declares no conflict of interest.

Open Access This article is distributed under the terms of the Creative Commons Attribution 4.0 International License (http://crea tivecommons.org/licenses/by/4.0/), which permits unrestricted use, distribution, and reproduction in any medium, provided you give appropriate credit to the original author(s) and the source, provide a link to the Creative Commons license, and indicate if changes were made.

\section{References}

Arshad M, Guillaume JHA, Ross A (2014) Assessing the feasibility of managed aquifer recharge for irrigation under uncertainty. Water 6:2748-2769

Bright J (2011) Projected effects of climate change on the proposed Lees Valley Irrigation scheme as part of the Canterbury Water Management Strategy. Aqualinc Research client report

Dillon P, Pavelic P, Page D, Beringen H, Ward J (2009) Managed aquifer recharge. In: An introduction waterlines report series no. 13. National Water Commission, Canberra, Australia

EOS Ecology (2011) Sites of ecological value within the Malvern and Ellesmere water race schemes, EOS Ecology report no. 10016SDC01-02, 18p

Golder Associates (2013) Selwyn-Te Waihora land and water planning: managing groundwater replenishment using managed aquifer recharge (MAR). Environment Canterbury report no. R13/114. Available online: http://files.ecan.govt.nz/public/lwrp/ variation $1 /$ managing-groundwater-replenishment-using-mana ged-aquifer-recharge.pdf. Accessed 22 Mar 2016

Goodman JM, Dunn NR, Ravenscroft PJ, Allibone RM, Boubee JAT, David BO, Griffiths M, Ling N, Hitchmough RA, Rolfe JR (2014) Conservation status of New Zealand freshwater fish, 2013. In: New Zealand threat classification series 7. Department of Conservation, Wellington, $12 \mathrm{p}$

Gutteridge AG, Haskins G, Davey GI; Australian Groundwater Technologies (2011) Feasibility of managed aquifer recharge for 
agriculture, waterlines report 45, National Water Commission, Canberra, Australia

Hardin G (1968) The tragedy of the commons. Science 162(3859):1243-1248

Lacher LJ, Turner DS, Gungle B, Bushman BM, Richter HE (2014) Application of hydrologic tools and monitoring to support managed aquifer recharge decision making in the Upper San Pedro River, Arizona, USA. Water 6:3495-3527

Larned ST, Hicks DM, Schmidt J, Davey AJH, Dey K, Scarsbrook M, Arscott DB, Woods RA (2007) The Selwyn River of New Zealand: a benchmark system for alluvial plain rivers. River Res Appl. doi:10.1002/rra.1054. Published online in Wiley InterScience (http://www.interscience.wiley.com). Accessed 12 Mar 2016

Memon PA, Painter BDM, Weber E (2010) Enhancing potential for ICM in NZ: a multi-scalar strategic perspective. Australas J Environ Manag 17:35-44

O'Brien L (2015) Canterbury mudfish in the Irwell River and Killinchy Swamp: Spring 2014-Summer 2015. Ichthyo-niche client report for Whakaora Te Waihora Project, 7p

Painter BDM (2009) Sustainable water allocation for families, fish and farming: a wicked problem or a wicked solution? In: Proceedings of 53rd Annual Conference of International Society for the Systems Science (ISSS), University of Queensland, Brisbane, Australia

Painter BDM, Bright JC (2006) Adaptive management of groundwater allocation: a NZ case study. In: Proceedings of AWRA Summer Specialty Conference, Montana
Painter BDM, Memon A (2007) Enhancing the potential for integrated water management in NZ through adaptive governance. In: Pahl-Wostl C, Kabat P, Möltgen J (eds) Adaptive and integrated water management: coping with complexity and uncertainty. Springer, Berlin

PDP (Pattle Delamore Partners) (2010) Preliminary strategic assessment of water infrastructure option 4: managed aquifer recharge; 80p. Available online: http://ecan.govt.nz/publications/Plans/ cwms-strategic-assessment-mar.pdf. Accessed 8 Mar 2016

Rawluk A, Curtis A, Sharp E, Kelly BFJ, Jakeman AJ, Ross A, Arshad M, Brodie R, Pollino CA, Sinclair D et al (2012) Managed aquifer recharge in farming landscapes using large floods: an opportunity to improve outcomes for the MurrayDarling Basin? Australas J Environ Manag 20:1-15

SKM (Sinclair Knight Merz) (2010) Managed aquifer recharge feasibility study, 89p. Available online: http://ecan.govt.nz/ publications/Plans/cw-managed-aquifer-recharge-feasibilitystudy-draft-v4.pdf. Accessed 8 Mar 2016

Weber EP, Memon PA, Painter BDM (2011) Science, society, and water resources in New Zealand: recognizing and overcoming a societal impasse. J Environ Policy Plan 13(1):49-69

Zammit C, Woods R (2011) Projected climate and river flow for the Waimakariri catchment for 2040s and 2090s. Prepared for Aqualinc Research Ltd. NIWA client report CHCH2011-025 